Provided for non-commercial research and education use. Not for reproduction, distribution or commercial use.

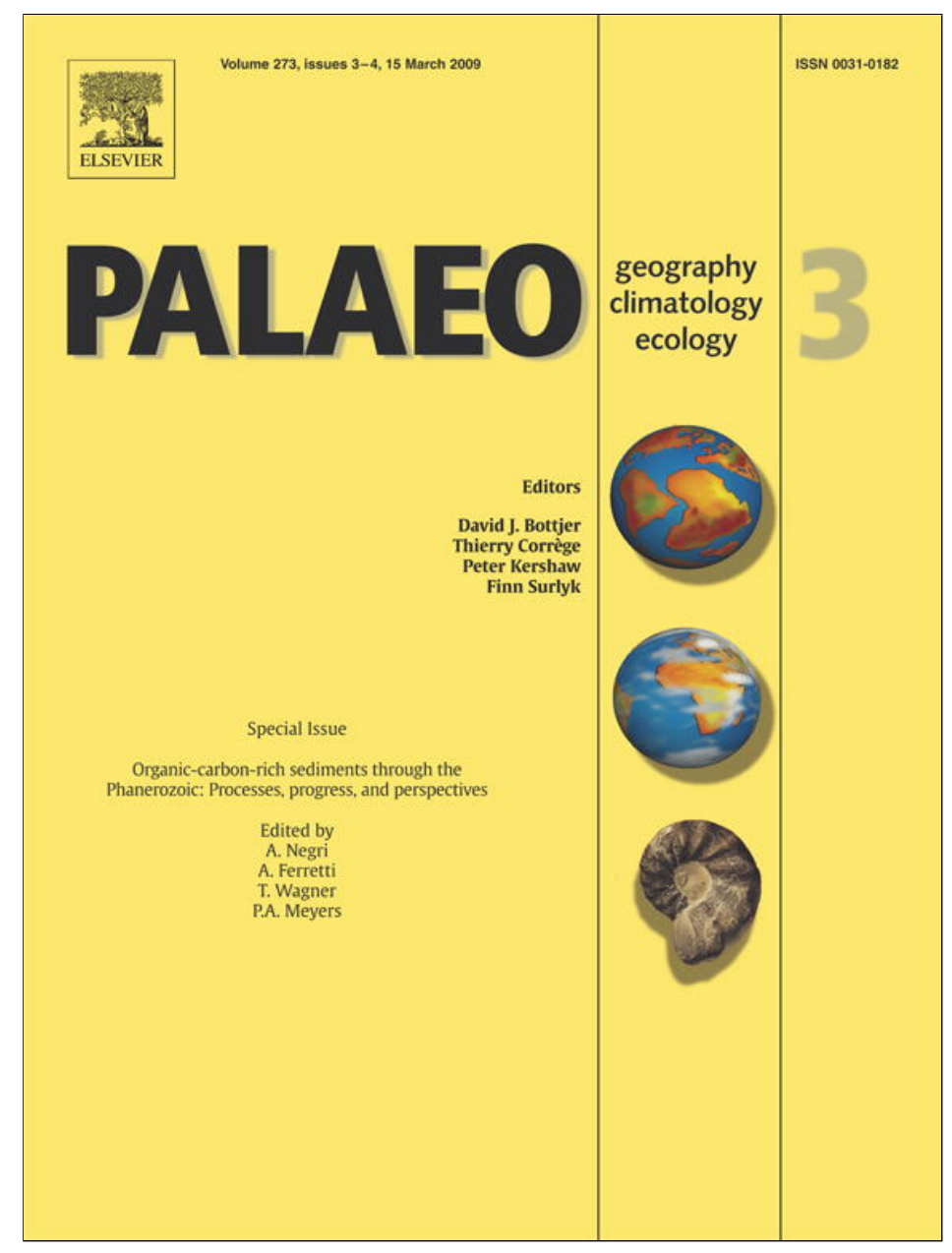

This article appeared in a journal published by Elsevier. The attached copy is furnished to the author for internal non-commercial research and education use, including for instruction at the authors institution and sharing with colleagues.

Other uses, including reproduction and distribution, or selling or licensing copies, or posting to personal, institutional or third party websites are prohibited.

In most cases authors are permitted to post their version of the article (e.g. in Word or Tex form) to their personal website or institutional repository. Authors requiring further information regarding Elsevier's archiving and manuscript policies are encouraged to visit:

http://www.elsevier.com/copyright 
Preface

\title{
Phanerozoic organic-carbon-rich marine sediments: Overview and future research challenges
}

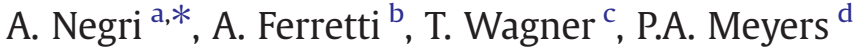 \\ a Dipartimento di Scienze del Mare, Università Politecnica delle Marche, Via Brecce Bianche, 60131 Ancona, Italy \\ b Dipartimento di Scienze della Terra, Università degli Studi di Modena e Reggio Emilia, Largo S. Eufemia, 41100 Modena, Italy \\ ${ }^{c}$ Department of Civil Engineering and Geosciences, Newcastle University, Newcastle upon Tyne, NE1 7RU, UK \\ ${ }^{d}$ Department of Geological Sciences, The University of Michigan, Ann Arbor, Michigan, 48109-1005, USA
}

A R T I C L E I N F O

\section{Article history:}

Received 3 October 2008

Accepted 9 October 2008

\section{Keywords:}

Anoxic oceans

Organic-carbon-rich marine sediments

Sapropel

Black shale

Cenozoic

Mesozoic

Palaeozoic

"One of the major obsessions of many early workers, to the mid1900s, was the application of uniformitarian principles to depositional models for black shales“ (Arthur and Sageman, 1994).

The purpose of this overview of organic-carbon(OC)-rich marine sediments is to provide a brief but current summary of the historical developments, principle concepts, and remaining challenges in integrated sapropel and black shale research. As such, it provides a substantive introduction to the Special Issue of Palaeogeography, Palaeoclimatology, Palaeoecology on "Organic Carbon Rich Sediments through the Phanerozoic: Processes, Progress, and Perspectives". Given this focused scope, the overview does not aim to be comprehensive or complete but to provide a solid setting for the fourteen individual research papers that constitute this Special Issue and two previous special issues (Meyers and Negri, 2003; Negri et al., 2006) that cover research aspects complementary to this one. Like the individual contributions, this introduction and overview is organized into Cenozoic, Mesozoic, and Palaeozoic units. The Cenozoic and Palaeozoic units are deliberately larger than the Mesozoic unit, acknowledging that much ground on Mesozoic black shale is already covered in the two previous special issues. Because the Late Cenozoic sapropels of the Mediterranean Basin have been extensively studied, understanding how

\footnotetext{
* Corresponding author.

E-mail address: a.negri@univpm.it (A. Negri).
}

these near-modern analogs of ancient black shales were deposited provides a good foundation for understanding how the older sequences may have evolved. In contrast, because far less is generally known about the black shales of the Palaeozoic than comparable OC-rich sequences of either the Cenozoic or the Mesozoic, a more comprehensive summary and comparison of the more ancient sequences is particularly appropriate to the theme of this Special Issue.

\section{Introduction}

Sediments rich in organic carbon are restricted to small areas along continental margins in the modern ocean and have rarely accumulated during the Cenozoic, yet organic-rich sediments were widely deposited during multiple intervals of Mesozoic-Palaeozoic time and even earlier during the Proterozoic-Archean. Global marine deposits document that episodes of accumulation of OC-rich sediments occurred in different regions and at different times. These episodes were linked to climatic and palaeoceanographic perturbations that resulted in massive fluctuations in hydrologic and nutrient cycles and in ocean chemistry and that recurred throughout geologic time. However, the paucity of surviving Palaeozoic and earlier black shale sections makes it difficult to impossible to recognize the internal structure of global events that are common in younger OC-rich sedimentary sequences.

As underlined below, the marine sections in many localities consist of intercalated carbonates and shales that may grade into pure carbonate or black shale sedimentation, often reflecting shallowing/ 
deepening of the depositional environments due to sea-level fluctuations superimposed on longer term orbital climate variability. Evidence for these past changes occurs at different time scales and in shallow to deep marine settings across all latitudes. Their temporal and spatial differences document regional overprinting and amplification or attenuation of global processes.

In the Late Cenozoic, laminated sections in expanded OC-rich sequences are sometimes found; they provide down to annual-scale palaeoclimate histories. Similar expressions of climate and sea-level variability are observed, although with less conclusive time control, in the Mesozoic, when "Oceanic Anoxic Events" (OAEs) were deposited in mid-Cretaceous marine environments that experienced a series of relatively short periods of rapid change with massive effects on the global carbon cycle. These short intervals evidently were associated with anoxic or even sulfidic (euxinic) conditions in the water column and were accompanied by widespread extinction events. The same mechanisms, episodes of widespread bottom water anoxia, have been postulated for Palaeozoic OC-rich sediments that record the long duration of these conditions and that accompany the Devonian and Permian extinction events, two of the major crises in life history.

After more than half a century from the first report of sapropels in deep sea sediments (Kullenberg, 1952) and more than 30 years after the basic paper of Schlanger and Jenkyns (1976) defining the OAEs as global phenomena, the significance of the burial of large amounts of organic matter in deep-sea sediments on the global carbon cycle and the nature of the palaeoceanographic and palaeoclimatic conditions leading to these peculiar deposits remain topics of lively debate. In this overview to Phanerozoic black shales, we briefly trace the history of sapropel and black shale studies since the first discovery of these OC-rich sequences to their modern interpretation, and we highlight recent achievements and remaining challenges in their research.

\section{Cenozoic organic-carbon-rich marine sequences}

\subsection{Investigations of Miocene-Holocene Mediterranean Sea sapropels}

The word "sapropel" is a combination of ancient Greek words sapros and pelos, meaning "putrefaction" and "mud", respectively. It is a term used in marine geology to describe dark-coloured, fine-grained sediments that are rich in amorphous organic matter. The historical definition of Mediterranean sapropels by Kidd et al. (1978) describes them as well-delimited layers within open marine sediments, with thickness $>1 \mathrm{~cm}$ and organic carbon content $>2 \%$. How such OC-rich layers were deposited in the oligotrophic Mediterranean Sea has been a subject of interest since Bradley (1938) first predicted the widespread occurrence of sapropels in the Mediterranean basins from study of exposures in southern Italy. He interpreted the sapropels as recording stagnation episodes during the Quaternary. Later, Kullenberg (1952) interpreted sapropel formation as resulting from interstitial salinity variations based on cores obtained by the 1948 Swedish Deep Sea Expedition. A decade later, Olausson (1961) presented a glacio-eustatic sea-level change model for sapropel formation that was subsequently variously reinterpreted by other authors (e.g., Chamley, 1971; Miller, 1972; Ryan, 1972; Nesteroff, 1973; Cita et al., 1973; McCoy, 1974). However, Olausson's classic glacio-eustatic model gradually became insufficient to explain all aspects of sapropel formation as more information about their properties accumulated.

DSDP Leg 42 recovered sapropel layers in cores of Pliocene to Quaternary sediments at multiple sites in the eastern Mediterranean. Some of these layers predate the onset of the strong glacial-interglacial cycles that affect eustatic sea level. Sigl et al. (1978) inferred that since the sapropels are interbedded as dark layers in more or less normal light-colored "open marine" sediments, the formation of these layers records short-lived but catastrophic alterations in oceanographic conditions that were probably caused by climate changes. They further suggested that differing faunal and lithological characteristics within sapropelic layers of different ages indicate different mechanisms of sapropel formation. Brongersma-Sanders (1957) had postulated that bituminous rocks may be formed when "either the supply of oxygen to the lower water layers is excessively low (persistent stagnation) or the supply of dead plankton and other oxidizable material is extremely high (hypertrophy)". Sigl et al. (1978) consequently inferred that the dual mechanisms of greater production and better preservation of organic matter may help to explain the presence of sapropelic sediments in "preglacial" lower Pleistocene and upper Pliocene sediments recovered by DSDP Leg 13 (Ryan et al., 1973; Cita, 1973), as well as in Miocene sediments recovered by DSDP Leg 42 . Moreover, the discovery of sapropelic sediments in the western Mediterranean (Kidd et al., 1978) revealed that their deposition was not entirely restricted to the eastern basin as had been believed until then. Therefore, new explanations for sapropel formation had to be considered.

Among the various processes that have been invoked to explain sapropel formation (see Rohling, 1994, and Rohling et al., in press, for reviews), variations on the classical "stagnation/anoxia" and the "increased productivity" models remain the most common. According to the stagnation/anoxia model, anoxic bottom conditions are caused by a strong stratification of the water column that prevents vertical mixing and oxygen supply to the bottom waters. In the Mediterranean, the origin of this stratification was explained as owing to increased Nile river runoff linked to the periodic enhancement of the East African monsoons (Rossignol-Strick, 1983, 1985) and, later, by increased rainfall and river discharge along the northern margins of the eastern Mediterranean Sea (Cramp et al., 1988; Rohling and Hilgen, 1991). In the "productivity" model, sapropel deposition is linked to enhanced organic matter flux from highly productive surface waters (Calvert, 1983; Calvert et al., 1992), inasmuch as the present production of organic matter in the eastern Mediterranean cannot account for the high values of total organic carbon (TOC) characterizing these layers (Calvert, 1983). In support of this view, evidence of a significant increase of productivity at times of sapropel deposition is revealed by palaeo-productivity proxies, such as Ba and marine barite concentrations (e.g., Thomson et al., 1995, 1999; Martinez-Ruiz et al., 2000, 2003; Gallego-Torres et al., 2007). To help explain the increased productivity, Sarmiento et al. (1988) and Howell and Thunell (1992) invoked a radical change from the modern anti-estuarine circulation to an estuarine circulation in the Mediterranean Sea.

After this first phase of research in which the scientific community tended to assume that the various causative processes were mutually exclusive, some authors (Rohling and Gieskes, 1989; Castradori, 1993; Rohling, 1994; Emeis et al., 1996, 2000) proposed a mechanism resulting from the combination of the two processes - stratification and productivity increase - that could have been caused by an increase of nutrient input via river runoff. However, questions remain regarding the extent and dynamics of the anoxic/dysoxic layer in the water column. The low-oxygen zone has been variously described as a near-surface zone in which oxygen becomes depleted (Sancetta, 1999; Meyers, 2006), a large water mass extending through much of the water column (Murat and Got, 2000; Stratford et al., 2000), and as an "anoxic blanket" that exists above the sediment/water interface (Casford et al., 2003).

Another fundamental question has centered on what organisms were responsible for the increased primary productivity and how they evolved through time. Are all of the multiple sapropel layers derived from organic matter made by the same group of primary producers? If not, how were environmental conditions different from location to location and through time? Kemp et al. (1999), for example, propose that diatom mats formed during summer seasons of prolonged stratification resulting from Nile run-off. These mats sank rapidly at the beginning of autumn-winter wind mixing and delivered massive loads of organic material to bottom sediments that quantitatively consumed the available oxygen in the water column. From massbalance calculations, Kemp et al. (1999) argue that all of the organic 
carbon retained in the sapropels could have been supplied by these diatoms. Although the mat model seems limited only to those uncommon sapropels containing diatom frustules, diatom opal is highly soluble, and therefore sapropels lacking diatom microfossils may once have contained them. Following this study, Sancetta (1999) argued that the diatom mechanism proposed might also apply to other OC-rich laminated strata, such as the 125-85 million-year-old mid-Cretaceous black shales.

A further multi-process interpretative step is typified by Meyers (2006), who suggested that increased continental runoff would have delivered abundant nutrients that would have first stimulated algal productivity, magnified export of organic matter, and increased midwater oxygen demand. The combination of surface water dilution, which increased salinity stratification of the upper water column and thereby discouraged mixing and mid-water ventilation, and magnified oxygen draw-down would have intensified and expanded the oxygen minimum zone (OMZ) such that anoxia intruded into the photic zone. After photosynthetic nitrogen-fixing bacteria and chemosynthetic archaea became established, their primary productivity would have first augmented and then potentially would have superseded that of the algae (e.g., Kuypers et al., 2001, 2002a,b). Accordingly the shift to microbe-amplified productivity would have persisted until climate reverted to less wet conditions that forced a return to less stratified, less productive and subsequently more oxygenated conditions in the surface ocean.

Recent approaches to investigate and to explain how sapropels were formed have evolved towards modeling methods. Studies on thermohaline circulation suggest that a weakening of the present-day anti-estuarine circulation in the Mediterranean can lead to the deposition of enough organic carbon to account for the formation of the upper Pleistocene-Holocene sapropels S5 to S1 (Myers et al., 2000; Stratford et al., 2000). Earlier sapropels may have similarly been deposited. More recently, Bianchi and co-authors (2006) suggested that modified thermohaline circulation supplying oxygen only to the upper $500 \mathrm{~m}$ of the water column, when coupled with increased productivity in the photic zone, can cause the development of an anoxic blanket at the sea-floor. Finally Meijer and Tuenter (2007) pointed out that the effects of (1) increased discharge of northern borderland rivers and (2) an increase in net precipitation over the sea itself are of equal or even greater importance than an increase in Nile discharge in diminishing ventilation of deep waters.

Deep-sea and outcrop sequences reveal that sapropels occur cyclically, strongly suggesting that they are related to the "Milankovitch cycles" linked to the Earth's orbital cycles of eccentricity (100-400 ky), obliquity (41 ky) and precession (19-22 ky). Correlation of the cyclic occurrence of sapropels in the Mediterranean to the orbital variations was achieved by Hilgen (1991a,b) and later refined by Hilgen et al. (1995), who developed a continuous record of sapropel occurrences as far back as the Late Miocene and correlated each sapropel to a well defined precession cycle. Because these orbital variations determine the global, seasonal and latitudinal distribution of solar insolation, they result in repetitive climatic fluctuations. As shown by Hilgen et al. (1995), sapropel deposition occurred during precession minima, when the northern hemisphere received maximum summer insolation and climate in the Mediterranean region was relatively wet.

The correlation of sapropel occurrences to orbital frequencies has great value to chronology because cyclo-stratigraphy in combination with other information, such as biostratigraphy and other sedimentological features, allows accurate age determinations, better estimates of sedimentation rates of individual sapropels, and comparison of sameage sapropel layers in different settings. These features are ultimately based on the orbital occurrence and the isochrony of each layer.

Recognition that the sapropel record is sensitive to post depositional oxidation has been growing. In recent times, a number of investigators have pointed out the potential of in situ oxidation in biasing the record of sapropels. Sapropels can evidently experience variable amounts of top- down oxidation after their deposition such that they rarely maintain their original thicknesses and compositional features (e.g., Löwemark et al., 2006; Larrasoaña et al., 2006; Thomson et al., 2006). One implication of this phenomenon is that the original thickness and TOC concentration of a specific sapropel layer can influence the rate and degree of post depositional oxidation. Another is that the sub-surface burial depth and the position of the depositional setting with respect to deep water circulation can both play major roles in the preservation of sapropels. Consequently, recognition of this phenomenon cautions against overinterpretation of sapropel presence or absence and over-dependence on them as geochronological tools. For example, post-depositional erasure of a weakly developed sapropel layer could badly skew an orbitally based timescale that does not take this possibility into consideration.

A particularly interesting and important finding of OC-rich layers in the western Mediterranean illustrates another potential problem with over-dependence on sapropels as geochronological markers and at the same time illuminates how OC-rich sediments can be deposited. Rogerson et al. (2008) describe OC-rich layers in post-glacial sediments of the Alboran Basin that could be confused with the widely expressed Holocene S1 sapropel. However, they demonstrate that the onset of the OC-rich layers predates the S1 sapropel by some 4-5 ky. They conclude that deposition of the Alboran Sea OC-rich layers was the result of a strong reduction in surface water density and a shoaling of the interface between the intermediate and deep waters during the latest deglacial period. Hence, the palaeoceanographic changes associated with OC-rich layers were much like those that are believed to have accompanied deposition of most of the sapropels in the greater Mediterranean Sea, but they were related to local processes in the Alboran Sea and not to precessional cycles.

\subsection{Other Cenozoic OC-rich sediments}

Although the Mediterranean sapropels are the most studied OC-rich Cenozoic sequences that are associated with low-oxygen depositional settings, similar sequences have been deposited in other semi-enclosed basins during this Era. Some examples are the Holocene Black Sea (Aksu et al., 1995; Giunta et al., 2007), the early Holocene Marmara Sea (KirciElmas et al., 2008), and the late-glacial Japan Sea (Tada et al., 1992; Khim et al., 2007). In addition, modern organic carbon-rich sediments are being deposited in unusual low-oxygen environments such as Mediterranean anoxic brine-filled basins (cf. Cita, 1991; Negri, 1996), and in silled near-shore basins such as the Santa Barbara Basin and the Cariaco Basin. Some of these locations are considered as modern or nearmodern analogs of the older depositional settings that favoured improved preservation of organic matter and led to accumulations of sapropels and black shales.

OC-rich sediments have also accumulated in Cenozoic settings that have not been low in oxygen. The best examples of such places are the large upwelling systems on the eastern margins of the modern-day Atlantic and Pacific oceans, where high rates of marine productivity are sustained by strong vertical mixing of the surface ocean. The high production of organic matter associated with eastern margin upwelling in the Atlantic started ca 7 Mya in the Late Miocene (Diester-Haass et al., 2002). An earlier onset of high productivity along the eastern margin of the Pacific is recorded by the Monterey Formation, which consists of laminated sediment enriched in organic carbon that was deposited during the Serravallian-Tortonian (14-7 Mya) Monterey event (Vincent and Berger, 1985). Subsequent study of the Monterey Formation has revealed that preservation of organic carbon is linked both to orbital-scale climate changes and to regional conditions during the Middle to Late Miocene (John et al., 2002). Other examples of studies into how OC-rich sediments accumulate under areas of high productivity include the Late Quaternary off northern Mexico (Ganeshram et al., 1999), the California Margin (last 60 ky; Dean, 2007). Finally, OC-rich sediments are known to accumulate in the Norwegian Greenland Sea, even if here organic matter has a residual origin being mainly derived from fossil reworked organic matter (last 60 ky; Wagner and Hölemann, 1995). 
Table 1

A summary of the mid-Cretaceous Oceanic Anoxic Events (OAEs). Approximate absolute-age durations are from Ogg et al. (2004) and Wagner et al. (2004)

\begin{tabular}{lllr}
\hline Event & Common name & Geologic time & \multicolumn{1}{c}{ Absolute duration } \\
\hline OAE 3 & (none) & Coniacian-Santonian & $87.3-84.6 \mathrm{Ma}(\sim 2.7 \mathrm{My})$ \\
OAE 2 & Bonarelli Event & Latest Cenomanian & $93.8-93.5 \mathrm{Ma}(\sim 300 \mathrm{ky})$ \\
OAE 1d & Breistroffer Event & Late Albian & $100.6-100.2 \mathrm{Ma}(\sim 400 \mathrm{ky}$ \\
OAE 1c & Tollebuc Event & Late Albian & $103.7-103.4 \mathrm{Ma}(\sim 300 \mathrm{ky})$ \\
& & & \\
OAE 1b series of sub-OAEs & & \\
& Urbino Event & Early Albian & $110.9-110.6 \mathrm{Ma}(\sim 300 \mathrm{ky})$ \\
& Paquier Event & Early Albian & $112.0-111.6 \mathrm{Ma}(\sim 400 \mathrm{ky})$ \\
& Jacob Event & Late Aptian & $113.6-113.2 \mathrm{Ma}(\sim 400 \mathrm{ky})$ \\
OAE 1a & Selli Event & Early Aptian & $124.2-123.4 \mathrm{Ma}(\sim 800 \mathrm{ky})$ \\
\hline
\end{tabular}

Episodes of regionally confined accumulations of OC-rich sediments also occurred earlier in the Cenozoic. Intervals of "black shales" have been recovered in Arctic sediments (Stein, 2007), the Tethyian margin in the North between the Crimea and Uzbekistan (Gavrilov et al., 1997) and the South in Egypt and Israel (Speijer and Wagner, 2002) that are related to the 6 My Paleocene-Eocene Thermal Maximum period of global warming (Zachos et al., 2008). Off equatorial West Africa porcellanites with enhanced organic carbon concentrations and good hydrocarbon potential were deposited during the Middle to Late Eocene (Wagner, 2002). Interesting shallow water Eocene laminated sediments exist in Tunisia (Henchiri, 2007). Sometimes these events are not fully developed (i.e., Eocene-Oligocene; Coccioni and Galeotti, 2003). Rhythmically bedded sediments occur in the Oligocene-Miocene sediments of the Paratethys that are postulated to be an earlier analog of the modern Black Sea (i.e., Kruge et al., 1996; Schulz et al., 2005).

\section{Mesozoic organic-carbon-rich marine sequences}

Extensive sequences of marine black shales containing 2 to 30\% organic carbon were episodically deposited from 183 My to $83 \mathrm{My}$ (Toarcian through Santonian ages) during the Mesozoic Era. Continuing investigations of the nature of the marine black shales and the processes leading to their formation have placed black shale research into the centre of today's debate on global warming and climate change. The foundations for the current focus on extreme warm climate, rapid biogeochemical cycling and associated climate/environmental change were established half a century ago when petroleum industries jointly developed the first integrated concepts to assess and predict general environmental boundary conditions and preferential depositional settings for oil-prone source rocks (e.g. the "Organic Facies" concept summarized by Jones, 1987). In parallel the rise of isotope and organic geochemistry enabled academia to postulate the fundamental concept of the "Oceanic Anoxic Events", or OAEs (Schlanger and Jenkyns, 1976) that are listed in Table 1. Both basic concepts have not lost attraction over time. Indeed, they have been merged with other critical aspects of Earth and Life Science and have substantially evolved into what is today a truly cross-disciplinary strategy to understand and quantify key elements of the Earth's climate system and how it interacts with the global carbon cycle.

Current research into the mid-Cretaceous OAEs serves as a focal point for research into extreme climate in a broader sense. Together with detailed investigation into the Late Paleocene Thermal Maximum (e.g., Speijer and Wagner, 2002; Zachos et al., 2005; Higgins and Schrag, 2006; Zachos et al., 2006; Schouten et al., 2007; Smith et al., 2007) and, although less well publicized, into OAE equivalents from the Jurassic (Hesselbo et al., 2000; Kemp et al., 2005; Cohen et al., 2007; Hesselbo et al., 2007; Pearce et al., 2008), the Miocene (Woodruff and Savin, 1991; Raymo, 1994; Pagani et al., 1999; Föllmi et al., 2005; Holbourn et al., 2007; Vincent and Berger, 1985), and the Plio-Pleistocene (see recent summary by Meyers, 2006), Cretaceous black shale research today addresses a wide range of questions that partly emerged from the original concepts. Taking particular advantage of the spectacular analytical progress in organic and isotope geochemistry and computer simulations over the last decade, the new challenges are beyond traditional discussions of OAEs. They include but are not limited to the short term dynamics of the climate system in a generally warmer world, processes and phase relationships connecting the atmosphere with the surface ocean (Dumitrescu et al., 2006; Forster et al., 2007; Wagner et al., 2008), orbital forcings (Beckmann et al., 2005; Gale et al., 2005; Sageman et al., 2006; Mitchell et al., 2008), regional effects on global processes, in particular the role of land-ocean interactions in driving ocean redox and shallow ocean circulation (Nederbragt et al., 2004; Wagner et al., 2004; Mort et al., 2007), nano-scale organo-mineral relationships (Kennedy et al., 2002), redox variability and its impact on element and nutrient cycling (Crusius et al., 1996; Pearce et al., 2008; Jenkyns et al., 2007; März et al., 2008), the role of microbial life in sustaining conditions favouring formation of black shale and utilizing carbon from them under modern conditions (deep biosphere) (Krumholz et al., 1997; Coolen et al., 2002; D'Hondt et al., 2004; Arndt et al., 2007), triggers, thresholds and time scales for punctuated climate perturbations involving the emplacement of large igneous provinces (Sen et al., 2006, Kuroda et al., 2007; Turgeon and Creaser, 2008)and biotic responses (Larson and Erba, 1999; Leckie et al., 2002), methane outbursts (see review in Jenkyns, 2003; Kemp et al., 2005), widespread but short term polar glaciation (Bornemann et al., 2008), and finally high-quality sedimentary climate records linked with biogeochemical and global climate models (Bice et al., 2006; Flögel and Wagner, 2006; Wagner et al., 2007), also allowing projections into the future (Flögel et al., 2008). In sum, these challenges address questions of global relevance where progress is still to be made. Progress often is hampered by the lack of basic constraints, including accurate chronology, knowledge of sedimentary parameters, and - importantly the lack of continuous expanded sediment sections necessary to extract sub-Milankovitch scale (centennial-millennial) climate change in the past. Despite gaps, recent achievements like those presented in this Special Issue show various promising avenues where Cretaceous black shale research in its wider sense is heading.

\section{Palaeozoic organic carbon rich sequences}

\subsection{A global view}

The Palaeozoic, spanning from 542 to 251 My, covers a period of about 290 My, exceeding the combined duration of the Mesozoic and Cenozoic eras. This long time interval has been characterized by a variety of environmental and palaeogeographic settings, for which any generalization is often too restrictive. Nevertheless, most of the Palaeozoic from the Cambrian to the Carboniferous, has been commonly regarded as a global greenhouse period (Berner, 1994; Berner and Kothavala, 2001), interrupted by major but short-lived ice ages in the Hirnantian (Late Ordovician), in the Late Devonian and in the Early Carboniferous (Achab and Paris, 2007).

The whole Palaeozoic is punctuated by a profusion of episodes of black shale deposition that represent a common and not unusual sediment for that time. Sections in many localities consist of intercalated carbonates and shales that may grade into pure carbonate or black shale sedimentation, often and simply reflecting shallowing/deepening of the depositional environment due to sea-level fluctuations. Most of the attention that has so far been given to OC-rich deposits in the Palaeozoic has mostly reflected economic interests in hydrocarbons and metals. Only recently a pure geochemical approach, including the application of the three broad categories of biomarkers, carbon isotopes and elemental compositions, has been attempted in order to understand the genesis and significance of these peculiar deposits.

According to Nowak (2007), "black shales are most often described as argillaceous, argillaceous-pelitic, argillaceous-siliceous and argillaceous- 
carbonate sediments with higher amounts of more or less transformed organic matter responsible for the black or dark grey colour of these sediments." The abundance of organic matter does not, per se, imply black shales. The Palaeozoic, in fact, is also characterized by fossiliferous OC-rich limestones (e.g. the Silurian-Devonian Orthoceras limestones bordering northern Gondwana), known for their black colour and whose high organic content is revealed by a peculiar bituminous smell and by the common inclusion of soft hydrocarbon nuclei.

Going ever deeper into the past, two factors keep playing a more and more fundamental role: preservation and time resolution. $\mathrm{OC}$ rich sediments, either in form of black shales or limestones, do not necessarily reflect periods of elevated deposition of high organic matter but may paradoxically simply represent times of better organic matter preservation. In this perspective, at least, a simple measure of the total organic content of the sample appears insufficient to define high deposition of organic matter. Then, even well-dated sequences do not offer the high-resolution records needed to fully document or delineate short-time processes. Within these limitations, at least three major black-shale depositional events appear to have particularly attracted the attention of Palaeozoic specialists.

\subsection{Carboniferous-Permian}

In the Early Carboniferous, many large continents were concentrated in the southern hemisphere, where an ice cap had covered the South Pole. The oceans between Euroamerica and Gondwana began to close and, by the end of the period, the western half of Pangea was already assembled. During the Permian, other major land masses collided with the final assembly of the single Supercontinent of Pangea, spreading over the equator with a pole to pole distribution. A new ocean was rapidly growing on its southern end, the Tethys, ready to assume a dominant role in the Mesozoic.

Two well-known OC-rich sediments developed in the Late Palaeozoic of Central Europe, respectively in the Late Carboniferous-Early Permian and in the Late Permian, the latter known as Kupferschiefer (TOC up to $20 \%$ ) and famous for the richness in copper and silver. A recent petrographic study of the organic matter preserved in these levels from SW Poland (Nowak, 2007) associates the older shales to an openlacustrine depositional environment with organic matter mostly of sapropelic origin. A peculiar distinct lamination of microscopic algal-rich laminae intercalated with thicker clay-rich laminae clearly indicates a seasonal deposition. The Late Permian OC rich sediments, having bituminite as major organic component, indicate deposition in a shallow marine depositional environment with very small terrestrial input (Nowak, 2007).

Herbert and Compton (2007) recently confirmed deposition in a glacio-lacustrine environment for lower Permian sediments of the Karoo Basin of South Africa, including black shale units and documenting transition from full glacial to non-glacial conditions. High surface-water productivity associated with these OC rich shales had been deduced by Faure and Cole (1999) in all southwestern Gondwana basins. Piper and Perkins (2004) applied a depositional model, established from traceelement accumulation rates in the Cariaco Basin, to the Permian Phosphoria Formation of northwest United States in order to unravel the palaeoceanography of its deposition. The investigated Permian unit is represented by a black phosphate deposit containing up to $15 \%$ organic carbon and deposited under conditions of $\mathrm{O}_{2}$ depletion. The study of Piper and Perkins (2004) led to recognition that the hydrography of the Permian Phosphoria Basin corresponds to modern upwelling environments, with a moderate primary productivity.

\subsection{Devonian}

In the Devonian, many of the Early Palaeozoic oceans were closing. Laurasia and Baltica collided, forming Laurussia, while the southern continents remained tied together in the supercontinent of Gondwana.
The Devonian was a time of widespread formation of black shales. Among these, Late Devonian OC-rich sediments have attracted special consideration as they coincide with mass-extinction pulses and global signals of marine anoxia. Two distinct black OC-rich horizons (Kellwasser horizons) characterize Late Frasnian sequences of Central Europe and North Africa and have recently been documented also in the United States (e.g., Bond and Wignall, 2005; de la Rue et al., 2007). Lower Frasnian black shales, with TOC up to $14 \%$, deposited diachronously in several North African areas and also in Europe (Lüning et al., 2004), and were associated with an anoxic phase (Frasnes event) preceding the Kellwasser events. In deeper basinal-settings, anoxic sediments rich in organic matter persisted for longer periods till the earliest Famennian (Joachimski et al., 2001; Bond et al., 2004). Another global event, the Hangenberg event, occurred in the latest Devonian in association with the second strong pulse of the Devonian extinction.

Several studies have dealt with these deposits reflecting, again, the usual dilemma between the two end-member factors: "preservation" versus "productivity" models. de la Rue et al. (2007) recently approached the Frasnian/Famennian boundary with a multiproxy study (by the use of chemical, sedimentological and biotic proxies) of the New Albany Shale, in Indiana, documenting a drastic change from acritarch- to prasinophytedominated associations across the F/F boundary, indicating basinal deeper-water settings receiving a continuous input of in situ marinederived organic matter in anoxic conditions. Bond et al. (2004) referred the Kellwasser events, studied in a broad range of European occurrences, to intense and widespread marine anoxia. In particular, the upper episode was interpreted as "an epicontinental seaway phenomenon, caused by the upward expansion of anoxia from deep basinal locales rather than an "oceanic" anoxic event that has spilled laterally into epicontinental settings." The same anoxic event appears to have been the only of the two Kellwasser episodes to be synchronous either across Europe (Bond et al., 2004) or the western United States (Bond and Wignall, 2005).

Joachimski et al. (2001) analyzed geochemically the Kellwasser horizons in Poland, there developed in carbonate sequences dominated by cephalopod limestones (TOC up to 4.9\%), owing to tropical to subtropical palaeolatitudes (Marynowski et al., 2000). According to Joachimski et al. (2001), the short term transgressive-regressive pulses identified at a global scale by Johnson et al. (1985) caused the spread of anoxic water in formerly well-aerated environments (with episodic euxinic conditions into the photic zone) and intensified continental runoff, with consequent higher supply of continentderived nutrients and increase in primary productivity. Evidences of photic zone euxinia and wildfires have been recently documented in Poland from a black shale horizon equivalent to the Hangenberg global event (Marynowski and Filipiak, 2007).

Buggisch et al. (2008) recently related three latest Devonian to earliest Pennsylvanian positive excursions in $\delta^{13} \mathrm{C}$, paralleled by the deposition of black shales in central, northwest and southern Europe, to concordant shifts in $\delta^{18} \mathrm{O}_{\text {apatite }}$ interpreted as signals of climatic cooling and ice accumulation at high latitudes.

\subsection{Ordovician}

The Ordovician was a period of intense plate dispersion with land masses mostly concentrated in the southern hemisphere and a vast oceanic area occupying the northern half of the globe. The different grade of dispersion of the palaeoplates produced a diverse degree of endemicity among marine biota. In addition, the new land-mass configuration led to the establishment of an active thermohaline oceanic circulation by the Middle-Late Ordovician resulting in an effective mixing of the pelagic elements and in an intense upwelling able to amplify phytoplankton production (Achab and Paris, 2007). By the end of the period, Gondwana regions were located at high latitudes in cold climates during the onset of a severe glaciation with the rapid build-up of a huge ice-cap. Other areas occupied tropical and subtropical latitudes, with carbonate deposits dominating in Baltica and, partially, in Laurentia. 
The glaciation at the end of the Ordovician has attracted interest not only for its association with a major extinction event, but also because it required unusual causes due to its short duration (approximately $1 \mathrm{My}$ ) during an otherwise warm period in Earth's climate, characterized by an atmospheric $\mathrm{CO}_{2}$ concentration that was 15-20 times its present level (Page et al., 2006). Several other minor glacial episodes appear to have been associated, and Page et al. $(2006,2007)$ recently referred to a glacial Early Palaeozoic Icehouse (Late Ordovician-early Silurian), marked by seven glacial maxima, intercalated by brief intervals of glacial ameliorations. OC-rich black shales containing up to $10 \%$ TOC were deposited extensively especially along the northern Gondwana shelf during the same time interval (e.g., Lüning et al., 2000; Armstrong et al., 2005; Le Heron et al., 2008). The short duration of the glaciation was explained by a rapid drawdown of atmospheric $\mathrm{CO}_{2}$ below a critical glacial inception threshold triggered by an amplification in marine productivity and consequent organic carbon burial (Brenchley et al., 1994, 1995). The increased phytoplankton production eventually led to the replacement of greenhouse by icehouse conditions (Achab and Paris, 2007). A similar approach was advanced by Page et al. (2006), who interpreted the deposition of graptolitic black shales as a negative feedback mechanism responsible for drawing down $\mathrm{CO}_{2}$ and preventing runaway melting in a peculiar climatic situation in which elevated atmospheric $\mathrm{CO}_{2}$ prohibited carbonate formation.

Armstrong et al. $(2005,2006)$ discussed and compared the upwelling and the silled basin models (either the elevated productivity or the enhanced preservation model) in order to interpret the deposition of Late Ordovician deglacial organic-rich black shales from Jordan. They favoured the "expanding puddle model" of Wignall (1994), suggesting that anoxic conditions were maintained for thousands of years due to a pronounced salinity stratification with a surface layer of fresher water derived by ice-melting. An intensified bioproductivity was sustained by continuous supply of meltwaterderived nutrients in the mixolimnion. With the onset of the deglacial transgression, black shales extended to marginal areas.

A different view had been proposed by Lüning et al. (2000), and discussed in Lüning et al. (2006), who favoured the basal transgressive black shale model for earliest Silurian oil shales from Arabia and North Africa, source of 80-90\% Palaeozoic hydrocarbons of North Africa and with up to $17 \%$ total organic content (Boote et al., 1998). They assembled a huge quantity of information, including unpublished petroleum exploration well data, and suggested that the melting of the Late Ordovician ice-cap produced a very rapid transgression in a strongly irregular palaeorelief. An almost instantaneous anoxic event was induced by a favourable combination of several factors in the Rhuddanian, persisting just 1-2 My and resulting in the exceptional preservation of the laterally discontinuous northern Gondwana OC-rich basal Silurian shales.

\subsection{Palaeozoic organic matter producers}

The Palaeozoic marks an interval of extraordinary and unparalleled achievements in the history of life. In the Early Palaeozoic, life existed in a solely marine scenario. By the Silurian, a dramatic innovative event was quickly occurring, with terrestrial environments that were subject to the rapid colonization and diversification of land plants. From then on, land plants strongly became able to modify the global carbon cycle and consequently the climatic history of the Earth, removing $\mathrm{CO}_{2}$ from the atmosphere and resulting in a significant and persistent storage of $\mathrm{CO}_{2}$ starting in the Devonian (Peters-Kottig et al., 2006). Even within terrestrial floras, significant revolutions occurred in the Palaeozoic. Edwards (1998) recognized four major evolutionary steps in Palaeozoic land plant evolution. Ordovician and Silurian vegetation is represented mainly by spores while tracheophytes (or vascular plants) began to radiate in the Late Silurian-Early Devonian. Seed-plants appeared in the Late Devonian and, by the Permian, gymnosperms became dominant. Berner (1998), by the use of GEOCARB II applied to the whole
Phanerozoic, revealed that the rise of vascular plants in the Palaeozoic "had one of the most dramatic effects on $\mathrm{CO}_{2}$ of any process occurring within the past 550 Ma." Important drops in $\mathrm{CO}_{2}$ occurred in the Devonian, due to intensive weathering of silicate rocks by deeply rooted plants, and in the Carboniferous and Permian, due to enhanced burial of organic matter resulting probably from production of microbially resistant plant remains such as lignin. By the Late Palaeozoic, either marine or terrestrial organisms were able to contribute to organic-rich sediments. At the end of the Permian, the most severe mass extinction of the life-history took place and a completely different life-scenario was opened.

In this context, which were the major producers of Palaeozoic organic matter? Schwark and Empt (2006) investigated sterane compositions in Late Ordovician to Late Permian rock samples in order to unravel the evolution and diversification of Palaeozoic phytoplankton (mainly represented by Cyanophytes, acritarchs and algae) and to recognize any signal recorded by algae that might document causes/effects of the extinction events. Their data revealed a stepwise but persistent increase in $\mathrm{C}_{28} / \mathrm{C}_{29}$-sterane ratio caused by a drastic change in the community structure of green algae at the Devonian/Carboniferous boundary and contemporary to a great decline of acritarchs. More primitive $\mathrm{C}_{29}$ sterane producing algae were in fact replaced by modern $\mathrm{C}_{28}$-sterane-producing algae. This event has the same fundamental significance as more recent floral revolutions like the appearance of haptophyte algae or diatoms (Schwark and Empt, 2006). A "phytoplankton blackout" resulting also from a massive drop of acritarchs at the Devonian/Carboniferous boundary developed between the Early Carboniferous and the Late Triassic. A similar gap was not reported among benthic invertebrates. The strong and persistent increase in the $\mathrm{C}_{28} / \mathrm{C}_{29}$-sterane ratio signal occurring at the Devonian/Carboniferous could reveal the appearance of a non encysting, hardly fossilizing algal group, as earlier suggested by Strothers (1996).

In the marine realm, graptolites also made an important contribution. Organic matter preserved in lower Silurian black shales from the Barrandian (Czech Republic) consists primarily of graptolites and subordinate chitinozoans (Suchý et al., 2002).

The study of terrestrial organic matter has recently attracted interest as a more detailed knowledge of terrestrial organic matter allows a correlation between terrestrial and oceanic realms, in order to determine if oceanic carbon perturbations are purely oceanographic in their extent or if they have affected the entire ocean-atmosphere system. Aromatic hydrocarbon biomarker analysis was performed on organic matter of terrestrial origin from Middle Devonian to Late Permian coal basins of the Euramerian flora realm (Armstroff et al., 2006), mostly consisting of a mixture of type II-III kerogen with TOC up to $81.5 \%$. According to palynological and palaeobotanical studies on Late Carboniferous Euramerican coal basins (Auras et al., 2006), a major change in the composition of coal-swamp floras happened during the Pennsylvanian, when the lycopod-dominated flora was replaced by a tree fern-dominated flora, and seed plants assumed a prominent role. Carbon isotopic ratios indicate that a $C_{3}$-photosynthetic pathway analogous to that of present $C_{3}$ plants had been already developed by the Late Carboniferous-Permian (Auras et al., 2006). Organic-geochemical investigations carried on Devonian, Carboniferous and Permian coals in a wide palaeogeographic scenario revealed that no significant changes in chemical composition of the organic matter accompanied the Late Palaeozoic rapid morphologic evolution of higher land plants (Wollenweber et al., 2006). Furthermore, land plant organic matter from a variety of late Silurian to Late Permian terrestrial successions was recently investigated by Peters-Kottig et al. (2006), revealing no remarkable influences in organic carbon isotopic composition due to climatic conditions.

Many of the most significant black shale episodes in the Palaeozoic strictly match with major crises in the history of life. Understanding what drives global diversity may be used to explain processes, such as mass extinctions, that control diversity and turnover at a variety of geographic and temporal scales. But what is the role/effect of organic 
carbon rich sediments in extinction events? The Late Ordovician twophase extinction events and the multi-staged Devonian events show a pronounced but short-lived increase of the $\mathrm{C}_{28} / \mathrm{C}_{29}$-sterane-ratios, reflecting possibly the development of more opportunistic species. The quick recovery of the ratio would indicate that, at least for the younger crisis, the Late Devonian extinctions did not produce any lasting fundamental changes in the assemblage of the phytoplanktonic green algae, and the dominant phytoplankton groups regain their older proportions. Prasinophyte algae, abundant in sediments deposited under oxygen depleted conditions, might have quickly adapted in the events and produced the recorded increase in $\mathrm{C}_{28}$ steranes, in analogy with the behaviour of recent prasinophytes (Schwark and Empt, 2006).

\section{Final remarks}

The aim of this Special Issue is to describe and discuss Phanerozoic OC-rich sediments while breaking the walls that have traditionally existed between Palaeozoic, Mesozoic and Cenozoic specialists, who too often confine and organize themselves into hermetic "time capsules". During the process of writing this overview and editing this Special Issue, we have realized that some substantial problems still hamper the Scientific Community in its approach to the study of OC-rich sediments.

In general, specialists of each Era work in completely different time scales that range from thousands to millions of years. This generalization implies that the "temporal magnification" through which scientists are facing the subject varies from the fine resolution of the Modern and Late Holocene to the extremely low resolution of the Early Palaeozoic. Speaking metaphorically, it is like studying the same object by SEM, with an optical microscope, or with naked eyes and comparing their results.

In addition, too often we recognized an exasperating use of the uniformitarianism principle in which models or opinions derived from recent examples are simplistically applied to any of the older "timeboxes". In actuality, physical and biological conditions (e.g., oxygen and $\mathrm{CO}_{2}$ ) have strongly varied through time. Palaeozoic black shales were clearly deposited in a $\mathrm{CO}_{2}$-dominated setting (see Berner, 1994, 1998), whereas younger deposits reflect a lower concentration of the same gas. Again, the nature of primary producers is not yet completely defined for pre-Jurassic production of organic matter. Furthermore, palaeogeographic scenarios reveal completely different worlds in terms of land masses, oceans, palaeolatitudes, etc. According to this, any attempt to model the deposition of OC-rich sediments through the Phanerozoic must necessarily be tuned with all these variables.

Another relevant point is that some of the Phanerozoic OC-rich sediments are defined as global events, like the Cretaceous OAE1a and OAE2, but some others appear to have had a more restricted and even localized significance. Studies on OC-rich sediments have so far been concentrated on specific areas or precise time slices (e.g., the Cretaceous and in here even more focused on specific isotopic excursions preserved in the sediments), while other periods of time have received much less attention. What clearly emerges now is the urgent need of recognizing which of these deposits are really local and which are really global (meaning that global is independent of latitude or physiography). This different attitude will probably require us to apply different approaches in search of possible interpretations and perhaps diverse mechanisms leading to the deposition of OC-rich sequences.

The three main issues described here need to be further investigated and are certainly worth answering. They should not be regarded as problems but, on the contrary, as opportunities for new achievements, in particular in the light of the current discussion on global warming. In our opinion, the Scientific Community must come to a multiple-time scale approach and to a constructive dialogue that better integrates data and models in order to be even more successful. These efforts, with an emphasis on the upscaling/downscaling of processes and effects/feedbacks, will lead to the identification of methodologies that may be used uniformly in the Cenozoic, Mesozoic and Palaeozoic.
If our target objective is global in nature and not restricted to any period of time, we will be able to test the validity of Processes in the recent as well as its application in the past, to obtain real Progress in the knowledge of OC-rich sediments, and to gain credibility for delineating true Perspectives for the future. That way integrated research into OC-rich sediments from the past may provide critical information that help to improving climate predictions into the future beyond the IPCC time horizon.

\section{References}

Achab, A., Paris, F., 2007. The Ordovician chitinozoan biodiversification and its leading factors. Palaeogeography, Palaeoclimatology, Palaeoecology 245, 5-19.

Aksu, A.E. Yaşar, D. Mudie, PJ. 1995. Paleoclimatic and paleoceanographic circumstances leading to development of sapropel layer S1 in the Aegean Sea. Palaeogeography, Palaeoclimatology, Palaeoecology 116, 71-101.

Armstroff, A., Wilkes, H., Schwarzbauer, J., Littke, R., Horsfield, B., 2006. Aromatic hydrocarbon biomarkers in terrestrial organic matter of Devonian to Permian age. Palaeogeography, Palaeoclimatology, Palaeoecology 240, 253-274.

Armstrong, H.A., Turner, B.R., Makhlouf, I.M., Weedon, G.P., Williams, M., Al Smadi, A., Abu Salah, A., 2005. Origin, sequence stratigraphy and depositional environment of an upper Ordovician (Hirnantian) deglacial black shale, Jordan. Palaeogeography, Palaeoclimatology, Palaeoecology 220, 273-289.

Armstrong, H.A., Turner, B.R., Makhlouf, I.M., Weedon, G.P., Williams, M., Al Smadi, A Abu Salah, A., 2006. Reply to "Origin, sequence stratigraphy and depositional environment of an upper Ordovician (Hirnantian) deglacial black shale, Jordan". Palaeogeography, Palaeoclimatology, Palaeoecology 230, 356-360.

Arndt, S. Brumsack, H.-J. Wirtz, K.W. 2007. Cretaceous black shales as active bioreactors: a biogeochemical model for the deep biosphere encountered during ODP Leg 207 (Demerara Rise). Geochimica et Cosmochimica Acta 70, 408-425.

Arthur, M.A., Sageman, B.B., 1994. Marine black shales: a review of depositional mechanisms and significance of ancient deposits. Annual Review of Earth and Planetary Sciences 22, 499-551.

Auras, S., Wilde, V., Hoernes, S., Scheffler, K., Püttmann, W., 2006. Biomarker composition of higher plant macrofossils from Late Palaeozoic sediments. Palaeogeography, Palaeoclimatology, Palaeoecology 240, 305-317.

Beckmann, B., Flögel, S., Hofmann, P., Wagner, T., 2005. Mid-Cretaceous African climate development and implications for the marine carbon cycle. Nature 437, 241-244.

Berner, R.A., 1994. GEOCARB II: a revised model for atmospheric $\mathrm{CO}_{2}$ over Phanerozoic time. American Journal of Science 294, 56-91.

Berner, R.A., 1998. The carbon cycle and $\mathrm{CO}_{2}$ over Phanerozoic time: the role of land plants. Philosophical Transactions of the Royal Society of London B 353, 75-82.

Berner, R.A., Kothavala, Z., 2001. GEOCARB III: a revised model of atmospheric $\mathrm{CO}_{2}$ over Phanerozoic time. American Journal of Science 301, 182-204.

Bianchi, D., Zavatarelli, M., Pinardi, N., Capozzi, R., Capotondi, L., Corselli, C., Masina, S. 2006. Simulation of ecosystem response during the sapropel S1 deposition event. Palaeogeography, Palaeoclimatology, Palaeoecology 235, 265-287.

Bice, K.L., Birgel, D., Meyers, P.A., Dahl, K.A., Hinrichs, K.U., Richard, D.N., 2006. A multiple proxy and model study of Cretaceous upper ocean temperatures and atmospheric $\mathrm{CO}_{2}$ concentrations. Paleoceanography 21. doi10.1029/2005PA001203.

Bond, D., Wignall, P.B., 2005. Evidence for Late Devonian (Kellwasser) anoxic events in the Great Basin, western United States. In: Over, J., Morrow, J., Wignall, P.B. (Eds.) Development in Palaeontology and Stratigraphy. Understanding Late Devonian and Permian-Triassic Biotic and Climatic Events, 20. Elsevier, pp. 225-261 (Chapter 9).

Bond, D., Wignall, P.B., Racki, G., 2004. Extent and duration of marine anoxia during the Frasnian-Famennian (Late Devonian) mass extinction in Poland, Germany, Austria and France. Geological Magazine 141, 173-193.

Boote, D.R.D., Clark-Lowes, D.D., Traut, M.W., 1998. Palaeozoic petroleum systems of North Africa. In: MacGregor, D.S., Moody, R.T.J., Clark-Lowes, D.D. (Eds.), Petroleum Geology of North Africa. Geological Society of London, Special Publication, 132, pp. 7-68.

Bornemann, A., Norris, R.D., Friedrich, O., Beckmann, B., Schouten, S., Sinninghe Damsté, J.S., Vogel, J., Hofmann, P., Wagner, T., 2008. Isotopic evidence for glaciation during the Cretaceous supergreenhouse. Science 319, 189-192.

Bradley, W.H., 1938. Mediterranean sediments and Pleistocene sea levels. Science 88, 376-379.

Brenchley, P.J., Carden, G.A.F., Marshall, J.D., 1995. Environmental changes associated with the "first strike" of the Late Ordovician mass extinction. Modern Geology 20, 69-82.

Brenchley, P.J., Marshall, J.D., Carden, G.A.F., Robertson, D.B.R., Long, D.G.F., Meidla, T. Hints, L., Anderson, T.F., 1994. Bathymetric and isotopic evidence for a short-lived Late Ordovician glaciation in a greenhouse period. Geology 22, 295-298.

Brongersma-Sanders, M., 1957. Mass mortality in the sea. In: Hedgpeth, P.W. (Ed.) Treatise on Marine Ecology and Paleoecology, Part 1. Geological Society of America Memoir, 67, pp. 941-1010.

Buggisch, W., Joachimski, M.M., Sevastopulo, G., Morrow, J.R., 2008. Mississippian $\delta^{13} C_{\text {carb }}$ and conodont apatite $\delta^{18} \mathrm{O}$ records-Their relation to Late Palaeozoic Glaciation. Palaeogeography, Palaeoclimatology, Palaeoecology 268 (3-4), 273-292. doi:10.1016/j. palaeo.2008.03.043

Calvert, S.E., 1983. Geochemistry of Pleistocene sapropel and associated sediments from the Eastern Mediterranean. Oceanologica Acta 6, 255-267.

Calvert, S.E., Nielsen, B., Fontugne, M.R., 1992. Evidence from nitrogen isotope ratios for enhanced productivity during formation of eastern Mediterranean sapropels. Nature 359, 223-225. 
Casford, J.S.L., Rohling, E.J., Abu-Zied, R.H., Fontanier, C., Jorissen, F.J., Leng, M.J., Schmiedel, G., Thomson, J., 2003. A dynamic concept for eastern Mediterranean circulation and oxygenation during sapropel 400 formation. Palaeogeography, Palaeoclimatology, Palaeoecology 190, 103-119.

Castradori, D., 1993. Calcareous nannofossils and the origin of eastern Mediterranean sapropels. Paleoceanography 8, 459-471.

Chamley, H., 1971. Recherches sur la sedimentation argileuse en Méditerranée. Sciences Géologiques Strasbourg, Mémoire 35, 1-225.

Cita, M.B., 1973. Inventory of biostratigraphical findings and problems. In: Ryan, W.B.F., Hsü, K.J., et al. (Eds.), Initial Reports of the Deep Sea Drilling Project, vol. 13, pp. 1045-1073.

Cita, M.B., 1991. Anoxic basins of the eastern Mediterranean: an overview. Paleoceanography 6, 133-141.

Cita, M.B., Chierici, M.A., Ciampo, G., Zei, M., D'Onofrio, S., Ryan, W.B.F., Scorziello, R., 1973. The Quaternary record in the Thyrrhenian and Ionian basins of the Mediterranean Sea In: Ryan, W.B.F., Hsü, K.J., et al. (Eds.), Initial Reports of the Deep Sea Drilling Project, 13, pp. 1263-1339.

Coccioni, R., Galeotti, S., 2003. Deep-water benthic foraminiferal events from the Massignano Eocene/Oligocene Boundary Stratotype Section and Point (central Italy): biostratigraphic, paleoecologic, and paleoceanographic implications. In: Prothero, D.R., Ivany, L.C., Nesbitt, E. (Eds.), From Greenhouse to Icehouse: The Marine Eocene-Oligocene Transition. Columbia University Press, pp. 438-452.

Cohen, A.S., Coe, A.L., Kemp, D.B., 2007. The late Paleocene-early Eocene and Toarcian (Early Jurassic) carbon-isotope excursions: a comparison of their timescales, associated environmental changes, causes and consequences. Journal of the Geological Society of London 164, 1093-1108.

Coolen, M.J.L., Cypionka, H., Sass, A.M., Sass, H., Overmann, J., 2002. Ongoing modification of Mediterranean Pleistocene sapropels mediated by prokaryotes. Science 296, 2407-2410

Cramp, A., Collins, M., West, R., 1988. Late Pleistocene-Holocene sedimentation in the NW Aegean Sea: a paleoclimatic-paleoceanographic reconstruction. Palaeogeography, Palaeoclimatology, Palaeoecology 68, 61-77.

Crusius, J., Calvert, S., Pedersen, T., Sage, D., 1996. Rhenium and molybdenum enrichments in sediments as indicators of oxic, suboxic and sulfidic conditions of deposition. Earth and Planetary Science Letters 145, 65-78.

Dean, W.E., 2007. Sediment geochemical records of productivity and oxygen depletion along the margin of western North America during the past 60,000 years: teleconnections with Greenland Ice and the Cariaco Basin. Quaternary Science Reviews 26, 98-114.

de la Rue, S.R., Rowe, H.D., Rimmer, S.M., 2007. Palynological and bulk geochemical constraints on the paleoceanographic conditions across the Frasnian-Famennian boundary, New Albany Shale, Indiana. International Journal of Coal Geology 71, 72-84.

D'Hondt, S., et al., 2004. Distributions of microbial activities in deep subseafloor sediments. Science 306, 2216-2221.

Diester-Haass, L., Meyers, P.A., Vidal, L., 2002. The late Miocene onset of high productivity in the Benguela upwelling area as part of a global pattern. Marine Geology 180, 87-103.

Dumitrescu, M., Brassell, S.C., Schouten, S., Hopmans, E.C., Sinninghe Damsté, J.S., 2006. Instability in tropical Pacific sea-surface temperatures during the early Aptian. Geology 34, 833-836.

Edwards, D., 1998. Climate signals in Palaeozoic land plants. Philosophical Transactions of the Royal Society of London B 353, 141-157.

Emeis, K.-C., Sakamoto, T., Wehausen, R., Brumsack, H.-J., 2000. The sapropel record of the eastern Mediterranean Sea-results of Ocean Drilling Program Leg 160. Palaeogeography, Palaeoclimatology, Palaeoecology 158, 371-395.

Emeis, K.-C., Shipboard Scientific Party of Leg 160, 1996. Paleoceanography and sapropel introduction. In: Emeis, K.C., Robertson, A.H.F., Richter, C., et al. (Eds.), Proceedings of the Ocean Drilling Program Initial Reports, vol. 160, pp. 21-27.

Faure, K., Cole, D.I., 1999. Geochemical evidence for lacustrine microbial blooms in the vast Permian Main Karoo, Paraná, Falkland Islands and Huab basins of southwestern Gondwana. Palaeogeography, Palaeoclimatology, Palaeoecology 152, 189-213.

Flögel, S., Hofmann, P., Beckmann, B., Bornemann, A., Norris, D., Wagner, T., 2008. Evolution of tropical watersheds and continental hydrology during the late Cretaceous greenhouse: marine carbon burial and possible implications for the future. Earth and Planetary Science Letters 274 (1-2), 1-13. doi:10.1016/j.epsl.2008.06.011.

Flögel, S., Wagner, T., 2006. Linking Mid-Cretaceous global climate modeling and geological marine proxy records-insights to insolation-driven coupling of atmospheric circulation and ocean properties. Palaeogeography, Palaeoclimatology, Palaeoecology 235, 288-304.

Föllmi, K.B., Badertscher, C., de Kaenel, E., Stille, P., John, C.M., Adatte, T., Steinmann, P., 2005. Phosphogenesis and organic-carbon preservation in the Miocene Monterey Formation at Naples Beach, California-The Monterey hypothesis revisited. Geological Society of America Bulletin 117, 589-619.

Forster, A., Schouten, S., Moriya, K., Wilson, P.A., Sinninghe Damsté, J.S., 2007. Tropical warming and intermittent cooling during the Cenomanian/Turonian oceanic anoxic event 2: Sea surface temperature records from the equatorial Atlantic. Paleoceanography 22, PA1219. doi10.1029/2006PA001349.

Gale, A.S., Kennedy, W.J., Voigt, S., Walaszczyk, I., 2005. Stratigraphy of the Upper Cenomanian-Lower Turonian Chalk succession at Eastbourne, Sussex, UK: ammonites, inoceramid bivalves and stable carbon isotopes. Cretaceous Research 26, 460-487.

Gallego-Torres, D., Martinez-Ruiz, F., Paytan, A., Jiménez-Espejo, F.J., Ortega-Huertas, M., 2007. Pliocene-Holocene evolution of depositional conditions in the eastern Mediterranean: Role of anoxia vs. productivity at time of sapropel deposition. Palaeogeography, Palaeoclimatology, Palaeoecology 246, 424-439.

Ganeshram, R.S., Calvert, S.E., Pedersen, T.F., Cowie, G.L., 1999. Factors controlling the burial of organic carbon in laminated and bioturbated sediments off NW Mexico: implications for hydrocarbon preservation. Geochimica et Cosmochimica Acta 63, 1723-1734.
Gavrilov, Y.O., Kodina, L.A., Lubchenko, I.Y., Muzylev, N.G., 1997. The late Paleocene anoxic event in epicontinental seas of peri-Tethys and formation of the sapropelite unit: sedimentology and geochemistry. Lithology and Mineral Resources 32, 427-450.

Giunta, S., Morigi, C., Negri, A., Guichard, F., Lericolais, G., 2007. Holocene biostratigraphy and paleoenvironmental changes in the Black Sea based on calcareous nannoplankton. Marine Micropaleontology 63, 91-110.

Henchiri, M., 2007. Sedimentation, depositional environment and diagenesis of Eocene biosiliceous deposits in Gafsa basin (southern Tunisia). Journal of African Earth Sciences 49, 187-200.

Herbert, C.T., Compton, J.S., 2007. Depositional environments of the lower Permian Dwyka diamictite and Prince Albert shale inferred from the geochemistry of early diagenetic concretions, southwest Karoo Basin, South Africa. Sedimentary Geology 194, 263-277.

Hesselbo, S.P., et al., 2000. Massive dissociation of gas hydrate during a Jurassic oceanic anoxic event. Nature 406, 392-395.

Hesselbo, S.P., Jenkyns, H.C., Duarte, L.V., Oliveira, L.C.V., 2007. Carbon-isotope record of the Early Jurassic (Toarcian) Oceanic Anoxic Event from fossil wood and marine carbonate (Lusitanian Basin, Portugal). Earth and Planetary Science Letters 253, 455-470.

Higgins, J.A., Schrag, D.P., 2006. Beyond methane: towards a theory for the PaleoceneEocene Thermal Maximum. Earth and Planetary Science Letters 245, 523-537.

Hilgen, F.J., 1991a. Astronomical calibration of Gauss to Matuyama sapropels in the Mediterranean and implication for the geomagnetic polarity time scale. Earth and Planetary Science Letters 104, 226-244.

Hilgen, F.J., 1991b. Extension of the astronomically calibrated (polarity) to the Miocene/ Pliocene boundary time scale. Earth and Planetary Science Letters 107, 349-368.

Hilgen, F.J., Krijgsman, W., Langereis, C.G., Lourens, L.J., Santarelli, A., Zachariasse, W.J., 1995. Extending the astronomical (polarity) time scale into the Miocene. Earth and Planetary Science Letters 136, 495-510.

Holbourn, A., Kuhnt, W., Schulz, M., Flores, J.A., Andersen, N., 2007. Orbitally-paced climate evolution during the middle Miocene "Monterey" carbon-isotope excursion. Earth and Planetary Science Letters 261, 534-550.

Howell, M.W., Thunell, R.C., 1992. Organic carbon accumulation in Bannock Basin evaluating the role of the productivity in the formation of eastern Mediterranean sapropels. Marine Geology 103, 461-471.

Jenkyns, H.C., 2003. Evidence for rapid climate change in the Mesozoic-Palaeogene greenhouse world. Philosophical Transactions of the Royal Society London, Series A 361, 1885-1916.

Jenkyns, H.C., Matthews, A., Tsikos, H., Erel, Y., 2007. Nitrate reduction, sulphate reduction, and sedimentary iron isotope evolution during the Cenomanian-Turonian ocean anoxic event. Paleoceanography 22, PA3208. doi10.1029/2006PA001355.

Joachimski, M.M., Ostertag-Henning, C., Pancost, R.D., Strauss, H., Freeman, K.H., Littke, R., Sinninghe Damsté, J.S., Racki, G., 2001. Water column anoxia, enhanced productivity and concomitant changes in $\delta^{13} \mathrm{C}$ and $\delta^{34} S$ across the FrasnianFamennian boundary (Kowala-Holy Cross Mountains/Poland). Chemical Geology $175,109-131$.

John, C.M., Föllmi, K., De Kaenel, E., Adatte, T., Steinmann, P., Badertscher, C., 2002 Carbonaceous and phosphate-rich sediments of the Miocene Monterey Formation at El Capitan State Beach, California, U.S.A. Journal of Sedimentary Research 72, 252-267.

Johnson, J.G., Klapper, G., Sandberg, C.A., 1985. Devonian eustatic fluctuations in Euramerica. Geological Society of America Bulletin 96, 567-587.

Jones, R.W., 1987. Organic facies. Advances in Petroleum Geochemistry 2, 1-80.

Kemp, A.E.S., Pearce, R.B., Koizumi, I., Pike, J., Rance, S.J., 1999. The role of mat-forming diatoms in the formation of Mediterranean sapropels. Nature 398, 57-61.

Kemp, D.B., Coe, A.L., Cohen, A.S., Schwark, L., 2005. Astronomical pacing of methane release in the Early Jurassic period. Nature 437, 396-399.

Kennedy, M.J., Pevear, D.R., Hill, R.J., 2002. Mineral surface control of organic carbon in black shale. Science 295, 657-660.

Khim, B.K., Bahk, J.J., Hyun, S., Lee, G.H., 2007. Late Pleistocene dark laminated mud layers from the Korea Plateau, western East Sea/Japan Sea, and their paleoceanographic implications. Palaeogeography, Palaeoclimatology, Palaeoecology 247, 74-87.

Kidd, R.B., Cita, M.B., Ryan, W.B.F., 1978. Stratigraphy of eastern Mediterranean sapropel sequences recovered during Leg $42 \mathrm{~A}$ and their paleoenvironmental significance. In: Hsü, K.J., Montadert, L., et al. (Eds.), Initial Reports of the Deep-Sea Drilling Project 42A. U.S. Government Printing Office, Washington, pp. 421-443.

Kirci-Elmas, E., Algan, O., Özkar-Öngen, Í., Struck, U., Altenbach, A.V., Sagular, E.K., Nazíc, A., 2008. Palaeoenvironmental investigation of sapropelic sediments from the Marmara Sea: a biostratigraphic approach to palaeoceanographic history during the Last Glacial-Holocene. Turkish Journal of Earth Sciences 17, 129-168.

Kruge, M.A., Mastalerz, M., Solecki, A., Stankiewicz, B.A., 1996. Organic geochemistry and petrology of oil source rocks, Carpathian Overthrust region, southeastern Polandimplications for petroleum generation. Organic Geochemistry 24, 897-912

Krumholz, L., McKinley, J., Ulrich, G., Suflita, J., 1997. Confined subsurface microbial communities in Cretaceous rock. Nature 386, 64-66.

Kullenberg, B., 1952. On the salinity of the water contained in marine sediments. Göteborgs Kungliga Vetenskaps- och Vitterhets-Samhaelles Handlingar 6, 3-37.

Kuroda, J., Ogawa, N.O., Tanimizu, M., Coffin, M.F., Tokuyama, H., Kitazato, H., Ohkouchi, N., 2007. Contemporaneous massive subaerial volcanism and late Cretaceous Oceanic Anoxic Event 2. Earth and Planetary Letters vol. 256, 211-223.

Kuypers, M.M.M., Blokker, P., Erbacher, J., Kinkel, H., Pancost, R.D., Schouten, S., Sinninghe Damsté, J.S., 2001. Massive expansion of marine archaea during a midCretaceous oceanic anoxic event. Science 293, 92-94.

Kuypers, M.M.M., Blokker, P., Hopmans, E.C., Kinkel, H., Pancost, R.D., Schouten, S., Sinninghe Damsté, J.S., 2002b. Archaeal remains dominate marine organic matter from the early Aptian oceanic anoxic event 1b. Palaeogeography, Palaeoclimatology, Palaeoecology 185, 211-234. 
Kuypers, M.M.M., Pancost, R.D., Nijenhuis, I.A., Sinninghe Damsté, J.S., 2002a. Enhanced productivity led to increased organic carbon burial in the euxinic North Atlantic basin during the late Cenomanian oceanic anoxic event. Paleoceanography 17, 1051. doi10.1029/222PA000569.

Larrasoaña, J.C., Roberts, A.P., Hayes, A., Wehausen, R., Rohling, E.J., 2006. Detecting missing beats in the Mediterranean climate rhythm from magnetic identification of oxidized sapropels (Ocean Drilling Program Leg 160). Physics of the Earth and Planetary Interiors 156, 283-293.

Larson, R.L., Erba, E., 1999. Onset of the mid-Cretaceous greenhouse in the BarremianAptian: Igneous events and the biological, sedimentary, and geochemical responses. Paleoceanography 14, 663-678.

Leckie, R.M., Bralower, T.J., Cashman, R., 2002. Oceanic anoxic events and plankton evolution: biotic response to tectonic forcing during the mid-Cretaceous. Paleoceanography 17, 1041. doi10.1029/2001PA000623.

Le Heron, D.P., Khoukhi, Y., Paris, F., Ghienne, J.-F., Le Herissé, A., 2008. Black shale, grey shale, fossils and glaciers: anatomy of the Upper Ordovician-Silurian succession in the Tazzeka Massif of eastern Morocco. Gondwana Research 14, 483-496.

Löwemark, L., Lin, Y., Chen, H.-F., Yang, T.-N., Beier, C., Werner, F., Lee, C.-Y., Song, S.-R. Kao, S.-J., 2006. Sapropel burn-down and ichnological response to late Quaternary sapropel formation in two $\sim 400$ ky records from the eastern Mediterranean Sea. Palaeogeography, Palaeoclimatology, Palaeoecology 239, 406-425.

Lüning, S., Craig, J., Loydell, D.K., Štorch, P., Fitches, B., 2000. Lowermost Silurian "hot shales" in North Africa and Arabia: regional distribution and depositional model. Earth Science Reviews 49, 121-200.

Lüning, S., Loydell, D.K., Štorch, P., Shahin, Y., Craig, J., 2006. Origin, sequence stratigraphy and depositional environment of an Upper Ordovician (Hirnantian) deglacial black shale Jordan-Discussion. Palaeogeography, Palaeoclimatology, Palaeoecology 230, 352-355.

Lüning, S., Wendt, J., Belka, Z., Kaufmann, B., 2004. Temporal-spatial reconstruction of the early Frasnian (Late Devonian) anoxia in NW Africa: new field data from the Ahnet Basin (Algeria). Sedimentary Geology 163, 237-264

Martinez-Ruiz, F., Kastner, M., Paytan, A., Ortega-Huertas, M., Bernasconi, S.M., 2000. Geochemical evidence for enhanced productivity during S1 sapropel deposition in the eastern Mediterranean. Paleoceanography 15, 200-209.

Martinez-Ruiz, F. Paytan, A. Kastner, M., González-Donoso, J.M., Linares, D. Bernasconi, S.M., Jimenez-Espejo, F.J., 2003. A comparative study of the geochemical and mineralogical characteristics of the S1 sapropel in the western and eastern Mediterranean. Palaeogeography, Palaeoclimatology, Palaeoecology 190, 23-37.

Marynowski, L., Filipiak, P., 2007. Water column euxinia and wildfire evidence during deposition of the Upper Famennian Hangenberg event horizon from the Holy Cross Mountains (central Poland). Geological Magazine 144, 569-595.

Marynowski, L., Narkiewicz, M., Grelowski, C., 2000. Biomarkers as environmental indicators in a carbonate complex, example from the Middle to Upper Devonian, Holy Cross Mountains, Poland. Sedimentary Geology 137, 187-212.

März, C., Poulton, S.W., Beckmann, B., Küster, K., Wagner, T., Kasten, S., 2008. Redox sensitivity of P cycling during marine black shale formation: dynamics of sulfidic and anoxic, non-sulfidic bottom waters. Geochimica et Cosmochimica Acta 72, 3703-3717.

McCoy, F.W., 1974. Late Quaternary sedimentation in the eastern Mediterranean Sea. Ph.D. Thesis, Harvard University, Cambridge, Massachusetts, 164 pp.

Meijer, P.Th., Tuenter, E., 2007. The effect of precession-induced changes in the Mediterranean freshwater budget on circulation at shallow and intermediate depth. Journal of Marine Systems 68, 349-365.

Meyers, P., 2006. Paleoceanographic and paleoclimatic similarities between Mediterranean sapropels and Cretaceous black shales. Palaeogeography, Palaeoclimatology, Palaeoecology 235, 305-320.

Meyers, P.A., Negri, A. (Eds.), 2003. Paleoclimatic and Paleoceanographic Records in Mediterranean Sapropels and Mesozoic Black Shales. Special Issue. Palaeogeography, Palaeoclimatology, Palaeoecology, vol. 190, pp. 1-480.

Miller, A.R., 1972. Speculations concerning bottom circulation in the Mediterranean Sea. In: Stanley, D.J. (Ed.), The Mediterranean Sea: A Natural Sedimentation Laboratory. Dowden, Hutchinson and Ross, Stoudsburg, PA, pp. 37-42.

Mitchell, R.N., Bice, D.M., Montanari, A., Cleaveland, L.C., Christianson, K.T., Coccioni, R. Hinnov, L.A., 2008. Oceanic anoxic cycles? Orbital prelude to the Bonarelli Level (OAE 2). Earth and Planetary Science Letters 267, 1-16.

Mort, H.P., Adatte, T., Föllmi, K.B., Keller, G., Steinmann, P., Matera, V., Berner, Z., Stüben, D., 2007. Phosphorus and the roles of productivity and nutrient recycling during oceanic anoxic event 2. Geology 35, 483-486.

Murat, A., Got, H., 2000. Organic carbon variations of the eastern Mediterranean Holocene sapropel: a key for understanding formation processes. Palaeogeography, Palaeoclimatology, Palaeoecology 158, 241-257.

Myers, P.G., Haines, K., Rohling, E.J., 2000. Modelling the paleocirculation of the Mediterranean: the last glacial maximum and the Holocene with emphasis on the formation of sapropel S1. Paleoceanography 13, 586-606.

Nederbragt, A., Thurow, J., Vonhof, H., Brumsack, H.-J., 2004. Modelling oceanic carbon and phosphorus fluxes: implications for the cause of the late Cenomanian Oceanic Anoxic Event (OAE2). Journal of the Geological Society London 161, 721-728.

Negri, A., 1996. Possible origin of laminated sediments of the anoxic Bannock Basin (eastern Mediterranean). Geo-Marine Letters 16, 101-107.

Negri, A., Wagner, T., Meyers, P.A. (Eds.), 2006. Causes and Consequences of Marine Organic Carbon Burial Through Time. Palaeogeography, Palaeoclimatology, Palaeoecology, vol. 235, pp. 1-320.

Nesteroff, W.D., 1973. Petrography and mineralogy of sapropels. In: Ryan, W.B.F., Hsü, KJ.,et al. (Eds.), Initial Reports of the Deep Sea Drilling Project, vol. 13. U.S. Government Printing Office, Washington, pp. 713-720.

Nowak, G.J., 2007. Comparative studies of organic matter petrography of the late palaeozoic black shales from Southwestern Poland. International Journal of Coal Geology 71, 568-585.
Ogg, J.G., Agterberg, F.P., Gradstein, F.M., 2004. The Cretaceous Period. In: Gradstein, F. Ogg, J., Smith, A. (Eds.), A Geologic Time Scale 2004. Cambridge University Press, pp. 344-383.

Olausson, E., 1961. Studies of deep-sea cores. Report of the Swedish Deep Sea Expedition 1947-1948, vol. 8, pp. 353-391.

Pagani, M., Freeman, K.H., Arthur, M.A., 1999. Late Miocene atmospheric $\mathrm{CO}_{2}$ levels and the expansion of C4 grasses. Science 285, 876-879.

Page, A., Williams, M., Zalasiewicz, J., 2006. Were transgressive black shales a negative feedback mechanism modulating glacio-eustatic cycles in the Early Palaeozoic Icehouse? Geophysical Research Abstracts 8, 09210.

Page, A., Zalasiewicz, J., Williams, M., 2007. Deglacial anoxia in the Early Palaeozoic Icehouse. 51st Palaeontological Association Annual Meeting, Uppsala, p. 77. 2007.

Pearce, C.R., Cohen, A.S., Coe, A.L., Burton, K.W., 2008. Molybdenum isotope evidence for global ocean anoxia coupled with perturbations to the carbon cycle during the Early Jurassic. Geology 36, 231-234.

Peters-Kottig, W., Strauss, H., Kerp, H., 2006. The land plant $\delta^{13} \mathrm{C}$ record and plant evolution in the Late Palaeozoic. Palaeogeography, Palaeoclimatology, Palaeoecology 240, 237-252.

Piper, D.Z., Perkins, R.B., 2004. A modern vs. Permian black shale: the hydrography, primary productivity, and water-column chemistry of deposition. Chemical Geology 206,177-197.

Raymo, M.E., 1994. The Himalayas, organic carbon burial, and climate in the Miocene. Paleoceanography 9, 399-404.

Rogerson, M., Cacho, I., Jimenez-Espejo, F., Reguera, M.I., Sierro, F.J., Martinez-Ruiz, F., Frigola, J., Canals, M., 2008. A dynamic explanation for the origin of the western Mediterranean organic-rich layers. Geochemistry, Geophysics, and Geosystems (G3) 9. doi:10.1029/2007GC001936.

Rohling, E.J., 1994. Review and new aspects concerning the formation of eastern Mediterranean sapropels. Marine Geology 122, 1-28.

Rohling, E.J., Abu-Zied, R., Casford, J.S.L., Hayes, A., Hoogakker, B.A.A., in press. The Mediterranean Sea: Present and Past. In: Woodward, J.C. (Ed.), The Physical Geography of the Mediterranean, Oxford.

Rohling, E.J., Gieskes, W.W.C., 1989. Late Quaternary changes in Mediterranean intermediate water density and formation rate. Paleoceanography 4, 531-545.

Rohling, E.J., Hilgen, F.J., 1991. The eastern Mediterranean climate at times of sapropel formation: a review. Geologie en Mijnbouw 70, 253-264.

Rossignol-Strick, M., 1983. African monsoons, an immediate climate response to orbital insolation. Nature 304, 46-49.

Rossignol-Strick, M., 1985. Mediterranean Quaternary sapropels, an immediate response of the African monsoon to variation of insolation. Palaeogeography, Palaeoclimatology, Palaeoecology 49, 237-263.

Ryan, W.B.F., 1972. Stratigraphy of Late Quaternary sediments in the Eastern Mediterranean. In: Stanley, D.J. (Ed.), The Mediterranean Sea: A Natural Sedimentation Laboratory. Dowden, Hutchinson and Ross, Stoudsburg, PA, pp. 149-170.

Ryan, W.B.F., Hsü, K.J., et al., 1973. Initial Reports of the Deep Sea Drilling Project, vol. 13. U.S. Government Printing Office, Washington. 514 pp.

Sageman, B.B., Meyers, S.R., Arthur, M.A., 2006. Orbital time scale and new C-isotope record for Cenomanian-Turonian boundary stratotype. Geology 34, 125-128.

Sancetta, C., 1999. The mystery of the sapropels. Nature 398, 27-29.

Sarmiento, J.L., Herbert, T., Toggweiler, J.R., 1988. Mediterranean nutrient balance and episodes of anoxia. Global Biogeochemical Cycles 2, 427-444.

Schlanger, S.O., Jenkyns, H.C., 1976. Cretaceous oceanic anoxic events: causes and consequences. Geologie en Mijnbouw 55, 179-184.

Schouten, S., Woltering, M., Rijpstra, W.I.C., Sluijs, A., Brinkhuis, H., Sinninghe Damsté, J.S 2007. The Paleocene-Eocene carbon isotope excursion in higher plant organic matter: Differential fractionation of angiosperms and conifers in the Arctic. Earth and Planetary Science Letters 258, 581-592.

Schulz, H.-M.,Bechtel, A., Sachsenhofer, R.F, 2005. The birth of the Paratethys during the Early Oligocene: from Tethys to an ancient Black Sea analogue? Global and Planetary Change 49, 163-176.

Schwark, L., Empt, P., 2006. Sterane biomarkers as indicators of Palaeozoic algal evolution and extinction events. Palaeogeography, Palaeoclimatology, Palaeoecology 240, 225-236.

Sen, G., Borges, M., Marsh, B.D., 2006. A Case for short duration of Deccan Trap eruption. EOS, Transactions American Geophysical Union 87, 197-204.

Sigl, W., Chamley, H., Fabricius, F., Giroud d'Argoud, G., Müller, J., 1978. Sedimentology and environmental conditions of sapropels. In: Hsü, K.J., Montadert, L., et al. (Eds.), Initial Reports of the Deep-Sea Drilling Project 42A. U.S. Government Printing Office, Washington, pp. 445-465.

Smith, F.A., Wing, S.L., Freeman, K.H., 2007. Magnitude of the carbon isotope excursion at the Paleocene-Eocene thermal maximum: the role of plant community change. Earth and Planetary Science Letters, 262, 50-65.

Speijer, R.P., Wagner, T., 2002. Transgressive black shales associated with the Late Paleocene Thermal Maximum (LPTM): organic geochemical and micropaleontological evidence from the southern Tethyan margin (Egypt). In: Koeberl, C., MacLeod, K.C. (Eds.), Catastrophic Events and Mass Extinctions: Impacts and Beyond. Geological Society of America, vol. 356, pp. 533-549.

Stein, R., 2007. Upper Cretaceous/lower Tertiary black shales near the North Pole: organic-carbon origin and source-rock potential. Marine and Petroleum Geology 24, 67-73.

Stratford, K., Williams, R.G., Myers, P.G., 2000. The impact of the circulation on sapropel formation in the Eastern Mediterranean. Global Biogeochemical Cycles 14,683-695.

Strothers, P.K., 1996. Acritarchs. In: Jansonius, J., McGregor, D.C. (Eds.), Palynology: Principles and Applications. American Association of Stratigraphic Palynologist Foundation, pp. 81-105.

Suchý, V., Sýkorová, I., Stejskal, M., Šafanda, J., Machovič, V., Novotná, M., 2002. Dispersed organic matter from Silurian shales of the Barrandian Basin, Czech 
Republic: optical properties, chemical composition and thermal maturity. International Journal of Coal Geology 53, 1-25.

Tada, R.R., Koizumi, I., Cramp, A., Rahman, A., 1992. Correlation of dark and light layers, and the origin of their cyclicity in the Quaternary sediments from the Japan Sea. In: Pisciotto, K.A., IngleJr. Jr., J.C., von Breymann, M.T., Barron, J., et al. (Eds.), Proceedings of the Ocean Drilling Program, Scientific Results, 127/128, pp. 577-601.

Thomson, J., Croudace, I.W., Rothwell, R.G., 2006. A geochemical application of the ITRAX scanner to a sediment core containing eastern Mediterranean sapropel units. In: Rothwell, R.G. (Ed.), New Techniques in Sediment Core Analysis, 267. Geological Society of London, Special Publication, pp. 65-77.

Thomson, J., Higgs, N.C., Wilson, T.R.S., Croudace, I.W., de Lange, G.J., van Sanvoort, P.J.M., 1995. Redistribution and geochemical behaviour of redox sensitive elements around S1, the most recent eastern Mediterranean sapropel. Geochimica et Cosmochimica Acta 59, 3487-3501.

Thomson, J., Mercone, D., de Lange, G.J., van Santvoort, P.J.M., 1999. Review of recent advances in the interpretation of eastern Mediterranean sapropel S1 from geochemical evidence. Marine Geology 153, 77-89.

Turgeon, S.C., Creaser, R.A., 2008. Cretaceous oceanic anoxic event 2 triggered by a massive magmatic episode. Nature Geosciences 454, 323-326 v.

Vincent, E., Berger, W.H., 1985. Carbon dioxide and polar cooling in the Miocene: The Monterey Hypothesis. In: Sundquist, E.T., Broecker, W.S. (Eds.), The Carbon Cycle and Atmospheric $\mathrm{CO}_{2}$ : Natural Variations Archean to Present. American Geophysical Union, Washington DC, American Geophysical Union, Geophysical Monograph 32, pp. 455-468.

Wagner, T., 2002. Organic sedimentation in the equatorial Atlantic: evolution from Cretaceous to early Quaternary depositional environments. Palaeogeography, Palaeoclimatology, Palaeoecology 179, 113-147.
Wagner, T., Herrle, J.O., Sinninghe Damsté, J.S., Schouten, S., Stüsser, I., Hofmann, P., 2008. Rapid warming and salinity changes of Cretaceous surface waters in the subtropical North Atlantic. Geology 36, 203-206.

Wagner, T., Hölemann, J.A., 1995. Deposition of organic matter in the NorwegianGreenland Sea during the past 2.7 million years. Quaternary Research 44, 355-366.

Wagner, T, Sinninghe Damsté,J., Beckmann, B.,Hofmann, P. 2004. Euxinia and primary production in Upper Cretaceous eastern equatorial Atlantic surface waters fostered orbital-driven formation of marine black shales. Paleoceanography 19. doi10.1029/ 2003PA000898.

Wagner, T., Wallmann, K., Stüsser, I., Herrle, J.O., Hofmann, P., 2007. Consequences of moderate $\sim 25,000$ yr lasting emission of light $\mathrm{CO}_{2}$ into the mid-Cretaceous ocean. Earth Planetary Science Letters 259, 200-211.

Wignall, P.B., 1994. Black Shales. Clarendon Press, Oxford. 127 pp.

Wollenweber, J., Schwarzbauer, J., Littke, R., Wilkes, H., Armstroff, A., Horsfield, B., 2006. Characterisation of non-extractable macromolecular organic matter in Palaeozoic coals. Palaeogeography, Palaeoclimatology, Palaeoecology 240, 275-304.

Woodruff, F., Savin, S.M., 1991. Mid-Miocene isotope stratigraphy in the deep sea: highresolution correlations, paleoclimatic cycles, and sediments preservation. Paleoceanography 6, 755-806.

Zachos, J.C., et al., 2005. Rapid acidification of the ocean during the Paleocene-Eocene thermal maximum. Science 308, 1611-1615.

Zachos, J.C., et al., 2006. Extreme warming of mid-latitude coastal ocean during the Paleocene-Eocene Thermal Maximum: Inferences from $\mathrm{TEX}_{86}$ and isotope data. Geology 34, 737-740.

Zachos, J.C., Dickens, G.R., Zeebe, R.E., 2008. An early Cenozoic perspective on greenhouse warming and carbon-cycle dynamics. Nature 451, 279-283. 